\title{
Marginal selenium deficiency down-regulates inflammation-related genes in splenic leukocytes of the mouse.
}

Citation for published version (APA):

Kipp, A. P., Banning, A., van Schothorst, E. M., Meplan, C., Coort, S. L. M., Evelo, C. T. A., Keijer, J., Hesketh, J., \& Brigelius Flohe, R. (2012). Marginal selenium deficiency down-regulates inflammationrelated genes in splenic leukocytes of the mouse. Journal of Nutritional Biochemistry, 23(9), 1170-1177. https://doi.org/10.1016/j.jnutbio.2011.06.011

Document status and date:

Published: 01/09/2012

DOI:

10.1016/j.jnutbio.2011.06.011

Document Version:

Publisher's PDF, also known as Version of record

Document license:

Taverne

Please check the document version of this publication:

- A submitted manuscript is the version of the article upon submission and before peer-review. There can be important differences between the submitted version and the official published version of record.

People interested in the research are advised to contact the author for the final version of the publication, or visit the DOI to the publisher's website.

- The final author version and the galley proof are versions of the publication after peer review.

- The final published version features the final layout of the paper including the volume, issue and page numbers.

Link to publication

\footnotetext{
General rights rights.

- You may freely distribute the URL identifying the publication in the public portal. please follow below link for the End User Agreement:

www.umlib.nl/taverne-license

Take down policy

If you believe that this document breaches copyright please contact us at:

repository@maastrichtuniversity.nl

providing details and we will investigate your claim.
}

Copyright and moral rights for the publications made accessible in the public portal are retained by the authors and/or other copyright owners and it is a condition of accessing publications that users recognise and abide by the legal requirements associated with these

- Users may download and print one copy of any publication from the public portal for the purpose of private study or research.

- You may not further distribute the material or use it for any profit-making activity or commercial gain

If the publication is distributed under the terms of Article 25fa of the Dutch Copyright Act, indicated by the "Taverne" license above, 


\title{
Marginal selenium deficiency down-regulates inflammation-related genes in splenic leukocytes of the mouse ${ }^{\text {is }}$
}

\author{
Anna P. Kipp ${ }^{\mathrm{a}, *}$, Antje Banning ${ }^{\mathrm{a}, 1}$, Evert M. van Schothorst ${ }^{\mathrm{b}}$, Catherine Méplan ${ }^{\mathrm{c}}$, Susan L. Coort ${ }^{\mathrm{d}}$, \\ Chris T. Evelo ${ }^{\mathrm{d}}$, Jaap Keijer ${ }^{\mathrm{b}}$, John Hesketh ${ }^{\mathrm{c}}$, Regina Brigelius-Flohéa \\ ${ }^{a}$ German Institute of Human Nutrition Potsdam-Rehbruecke, Germany \\ ${ }^{\mathrm{b}}$ Human and Animal Physiology, Wageningen University, Wageningen, The Netherlands \\ ${ }^{\mathrm{I} I n s t i t u t e}$ for Cell and Molecular Biosciences, The Medical School, Newcastle University, UK \\ ${ }^{\mathrm{d}}$ Department of Bioinformatics-BiGCaT, Maastricht University, The Netherlands
}

Received 9 March 2011; received in revised form 21 June 2011; accepted 29 June 2011

\begin{abstract}
Moderate selenium deficiency may lead to an impaired capacity to cope with health challenges. Functional effects of suboptimal selenium intake are not fully known, and biomarkers for an insufficient selenium supply are inadequate. We therefore fed mice diets of moderately deficient or adequate selenium intake for 6 weeks. Changes in global gene expression were monitored by microarray analysis in splenic leukocytes. Genes for four selenoproteins, Sepw1, Gpx1, Selh and Sep15, were the most significantly down-regulated in moderate selenium deficiency, and this was confirmed by quantitative polymerase chain reaction (qPCR). Classification of significantly affected genes revealed that processes related to inflammation, heme biosynthesis, DNA replication and transcription, cell cycle and transport were affected by selenium restriction. Down-regulation by moderate selenium deficiency of specific genes involved in inflammation and heme biosynthesis was confirmed by qPCR. Myeloperoxidase and lysozyme activities were decreased in selenium-restricted leukocytes, providing evidence for functional consequences. Genes for 31 nuclear factor (NF)- $\kappa B$ targets were down-regulated in moderate selenium deficiency, indicating an impaired NF- $\kappa B$ signaling. Together, the observed changes point to a disturbance in inflammatory response. The selenoproteins found here to be sensitive to selenium intake in murine leukocytes might also be useful as biomarkers for a moderate selenium deficiency in humans.
\end{abstract}

(c) 2012 Elsevier Inc. All rights reserved.

Keywords: Selenium; Inflammation; Leukocytes; Selenoproteins; Gene expression; Microarray

\section{Introduction}

Selenium is an essential micronutrient with various functions which are mainly exerted by selenoproteins containing selenium in the form of selenocysteine. There are only 25 genes for selenoproteins in humans and 24 in mice [1]. While members of the enzyme families of thioredoxin reductases (TrxR), glutathione peroxidases (GPx) and deiodinases (DIO) are well characterized to be involved in cellular redox homeostasis and thyroid hormone metabolism, respectively, functions of the other selenoproteins are still not fully elucidated. Until now, a putative role for the remaining selenoproteins in redox regulation seems to prevail, which can be anticipated from a

The work was financially supported by the Nutrigenomics Organisation (NUGO) and the German Research Council (DFG), grant Br778/8-1.

* Corresponding author. Department Biochemistry of Micronutrients, German Institute of Human Nutrition Potsdam-Rehbruecke, Arthur-Scheunert-Allee 114-116, D-14558 Nuthetal, Germany. Tel.: +49 3320088 2333; fax: +493320088407 .

E-mail address: annakipp@dife.de (A.P. Kipp).

${ }^{1}$ Present address: Biochemical Institute, Justus Liebig University Giessen, Germany. thioredoxin-like structure identified in SelH, SelM, SelT, SelV, SelW and Sep15. In addition, many selenoproteins are localized in the endoplasmatic reticulum (ER), including SelS, Sep15, SelK, SelM and SelT (reviewed in [2]).

Beneficial effects of selenium/selenoproteins have been proposed in the prevention of cancer development [3], in male reproduction [4] and in the onset of AIDS in HIV-positive patients [5,6]. An emerging field is the role of selenium and selenoproteins in inflammation $[7,8]$, but underlying molecular mechanisms are still unclear. It is known that a severe selenium deficiency together with a coxsackie B virus infection results in the Keshan disease, an endemic cardiomyopathy [9]. Although this disease is not prevalent in countries where a severe selenium deficiency does not exist, a suboptimal selenium supply still persists in Europe, and this might affect immune function [10]. Critically ill patients, e.g., those suffering from sepsis, exhibit decreased plasma selenium levels, which are negatively correlated with their chance of survival [11]. Selenium supplementation of these patients reduced mortality in several clinical studies [12,13].

In vitro studies on the effect of selenium deficiency on inflammatory parameters have given apparently conflicting results, and this may be due partly to differences between cell lines: for example, on the one hand, the macrophage-like cell line RAW 264.7 showed a 
higher lipopolysaccharide (LPS)-induced expression of proinflammatory mediators, such as tumor necrosis factor (TNF) $\alpha$ [14], as well as a higher production of prostaglandins (PG) such as $\mathrm{PGE}_{2}$ [15] in selenium deficiency. TNF $\alpha$ is a known inducer of adhesion molecules like vascular cell adhesion molecule 1 (VCAM1) and intercellular adhesion molecule 1 , which are required for monocyte adhesion to endothelial cells and subsequent tissue penetration, a process counteracted by selenium supplementation [16]. In addition, VCAM1 expression is decreased in cells overexpressing the selenoprotein GPx4 [17]. The increase in LPS-induced $\mathrm{PGE}_{2}$ production depends on cyclooxygenase 2 (COX-2), which is down-regulated by selenium supply [14] and GPx2 [18]. Under these conditions, metabolism of arachidonic acid is shifted from $\mathrm{PGE}_{2}$ production to the synthesis of 15 -deoxy-PGJ 2 [19], an anti-inflammatory prostaglandin [20]. On the other hand, the LPS-induced release of TNF $\alpha$, interleukin (IL)-1 and IL-4 was increased in seleniumsupplemented J774.1 macrophage-like cells compared to seleniumdeficient cells [21].

The spleen, together with lymph nodes and mucosal-associated lymphoid tissues, comprises the majority of peripheral immune tissues. It is involved in blood filtering, iron recycling, antibody production and both innate and adaptive immunity [22]. In addition, it serves as a reservoir for monocytes and platelets. After splenectomy, the risk of developing sepsis is 10 - to 20 -fold increased [23]. The sensitivity of the spleen to selenium supply has been indicated by several studies. Feeding a high-selenium diet $(15 \mathrm{mg} / \mathrm{kg}$ diet $)$ inhibited proliferation and increased apoptosis in chicken splenocytes [24]. Similarly, splenocyte numbers were reduced upon feeding a diet excessive in selenium ( $2 \mathrm{ppm}$ selenomethionine). However, the same effects were observed after feeding a selenium-deficient $(0.02 \mathrm{ppm}$ selenomethionine) diet [25], underlining the requirement for a balanced selenium supply.

Most of the studies investigating selenium effects focus on deficient or supranutritional selenium levels. There are only a few studies dealing with consequences of a moderate selenium deficiency comparable with that which could arise due to normal variations in nutritional habits or seasonal food choice. These studies focused on the impact of a moderate selenium deficiency on antigen-specific $\mathrm{CD}^{+} \mathrm{T}$-cell responses and on allergic airway inflammation, respectively $[26,27]$. In our previous study, global gene expression under a moderate selenium deficiency compared to selenium-adequacy was analyzed in the colon of mice [28]. Four selenoproteins (Gpx1, Sepw1, Selh, Selm) most sensitively responding to the selenium status by changes in mRNA expression were found. In addition, pathways of protein biosynthesis, inflammation and Wnt signaling were significantly affected [28]. In the current study, splenic leukocytes from these mice were used to analyze the impact of selenium on global gene expression. The results from microarray and quantitative polymerase chain reaction (qPCR) measurements show that the small change in selenium intake influenced expression of specific selenoproteins and genes involved in the inflammatory response and heme biosynthesis. Mouse data roughly correlate with human data from the SELGEN study [29]. Since blood cells are relatively easily available from humans, the findings might be useful to identify reasonable biomarkers for the selenium status in humans.

\section{Methods and materials}

\subsection{Animal experiment}

Leukocytes were obtained from the animals treated as reported previously [28]. Briefly, groups of 12 male C57BL/6J mice (3-4 weeks of age) were fed either a selenium-deficient $(0.086 \mathrm{mg} \mathrm{Se} / \mathrm{kg})$ or a selenium-adequate diet $(0.15 \mathrm{mg} \mathrm{Se} / \mathrm{kg}$; representing the estimated nutrient requirements of mice [30]) produced by mixing selenomethionine (Acros, Geel, Belgium) into the deficient diet (Altromin, Lage, Germany). After a 6-week feeding period, animals were anesthetized with isoflurane, and blood was withdrawn with heparinized capillaries by puncture of the retroorbital plexus. Plasma was obtained after centrifugation of the blood for $10 \mathrm{~min}\left(3000 \mathrm{~g}, 4^{\circ} \mathrm{C}\right)$ and was stored at $-80^{\circ} \mathrm{C}$. Anesthetized animals were sacrificed by cervical dislocation. The animal study was approved by the Governmental Animal Ethics Committee (MLUV 32-44457141).

\subsection{Isolation of splenic leukocytes}

Spleens were removed aseptically, placed on a sterile microscope slide and crushed with the end of a 6-ml syringe plunger. Released cells were diluted in $5 \mathrm{ml}$ of cell culture medium (RPMI with 5\% fetal calf serum; Gibco, Karlsruhe, Germany). Clumps were dispersed by drawing and expelling the suspension repeatedly through a 6 -ml syringe with a 20-gauge needle. A 100-um mesh was used to remove clumps and particles and to receive a single cell suspension. The mesh was rinsed with $5 \mathrm{ml}$ RPMI. After centrifugation ( $5 \mathrm{~min}, 200 \mathrm{~g}$ ) and washing with $10 \mathrm{ml} \mathrm{RPMI}$, erythrocytes were lysed for $5 \mathrm{~min}$ in $5 \mathrm{ml}$ of ammonium chloride lysis buffer $\left(0.15 \mathrm{~mol} / \mathrm{L} \mathrm{NH}_{4} \mathrm{Cl}, 10 \mathrm{mmol} / \mathrm{L}\right.$ $\mathrm{KHCO}_{3}, 0.1 \mathrm{mmol} / \mathrm{L} \mathrm{Na} \mathrm{N}_{2} \mathrm{EDTA}, \mathrm{pH} 7.4$ ). Thereafter, $15 \mathrm{ml}$ of balanced salt solution containing $0.2 \%$ bovine serum albumin was added, and the suspension was centrifuged for $5 \mathrm{~min}$ at 200g. The pellet was suspended in $1 \mathrm{ml}$ phosphate-buffered saline (PBS) and transferred into a 2-ml tube. Thirty microliters of the suspension was smeared on microscope slides and dried on air for counting. The cells of the remaining suspension were pelleted ( $5 \mathrm{~min}, 200 \mathrm{~g}$ ) and washed with $1 \mathrm{ml} \mathrm{PBS}$. The pellet was frozen at $-80^{\circ} \mathrm{C}$ until RNA isolation. As determined with May-Grünwald-Giemsa staining, the leukocyte population was independent of the selenium status and on average was composed of $79 \%$ lymphocytes, $18 \%$ granulocytes and $2 \%$ monocytes. In addition, spleen weight was unaffected by the selenium status.

\subsection{RNA isolation}

Whole cell pellets of splenic leukocytes were suspended in $800 \mu \mathrm{l}$ of cold Trizol (Invitrogen, Karlsruhe, Germany) and homogenized with a TissueLyser (Qiagen, Hilden, Germany) for $2 \times 2 \mathrm{~min}$ at $30 \mathrm{~Hz}$. Total RNA was isolated using the Trizol protocol according to the manufacturer's instructions and RNeasy mini columns (Qiagen). RNA quality was checked using a Bioanalyzer 2100 (Agilent Technologies, Böblingen, Germany). RNA samples subsequently used for microarray analysis had an RNA integrity number $>9.0$.

\subsection{Microarray and pathway analysis}

The microarray analysis using Mouse 44K microarrays (G4122A; Agilent Technologies, Inc., Santa Clara, CA, USA) was done according to the published protocol [31] as described [28]. The RNA of 12 animals per group was individually hybridized to microarrays using a reference pool design. Significantly regulated genes were identified with Student's $t$ test without $(P<.05)$ or with false discovery rate (FDR) analysis at a cutoff of 0.05 according to the Benjamini-Hochberg procedure [32]. Indicated genes were classified manually based on gene ontology (GO) terms for the process and function categories which are additionally provided as Supplementary Table S1. The visualization and analysis tool, PathVisio, was used to perform pathway analysis [33]. In this analysis, the WikiPathways curation analysis pathway collection for mice [34] and the mouse gene database version 20100601 were used. Pathways were ranked based on a $z$-score.

\subsection{Quantitative real-time $P C R$}

RNA ( $3 \mu \mathrm{g}$ ) was reversely transcribed with $150 \mathrm{fmol}$ oligo(dT) 15 primers and $180 \mathrm{U}$ Moloney murine leukemia virus reverse transcriptase (Promega) in a total volume of $45 \mu$ l. Real-time PCRs (Mx3005P QPCR System; Stratagene, Amsterdam, the Netherlands) were performed in triplicates with $1 \mu \mathrm{l}$ of twofold-diluted cDNA in $25-\mu \mathrm{l}$ reaction mixtures using SYBR Green I (Molecular Probes, Eugene, OR, USA) as fluorescent reporter. The annealing temperature was $60^{\circ} \mathrm{C}$ for all PCRs. PCR products were quantified with a standard curve ranging from $10^{4}$ to $10^{9}$ copies of each amplicon. Primers (Table 1, Sigma-Aldrich; for selenoproteins, see Ref. [28]) were designed to be specific for cDNA by placing at least one primer onto an exon/intron boundary with PerlPrimer v1.1.14. The mean of the selenium-insensitive reference genes Rpl13a and Hprt1 [28] was used for normalization [35].

\subsection{Preparation of protein lysates}

Leukocyte pellets were suspended in $250 \mu \mathrm{l}$ homogenization buffer $(100 \mathrm{mmol} / \mathrm{L}$ Tris- $\mathrm{HCl}, 300 \mathrm{mmol} / \mathrm{L} \mathrm{KCl}$ and $0.1 \%$ Triton X-100, pH 7.6) containing $2 \mu \mathrm{l}$ of protease inhibitor cocktail III (Calbiochem, Bad Soden, Germany) and homogenized with a TissueLyser (Qiagen) for $2 \times 2 \mathrm{~min}$ at $30 \mathrm{~Hz}$. All lysates were centrifuged for $15 \mathrm{~min}$ at $20,000 \mathrm{~g}$ and $4^{\circ} \mathrm{C}$ before protein content was estimated according to Bradford [36]. Samples were stored at $-80^{\circ} \mathrm{C}$.

\subsection{GPx activity}

GPx activity was measured in the glutathione reductase-coupled test optimized for tissue samples [37]. A total of $2.5 \mu \mathrm{l}$ plasma or $4 \mu \mathrm{l}$ leukocyte lysate was measured in a total volume of $250 \mu \mathrm{l}$ in a 96-well microtiter plate absorbance reader (Synergy 2; 
Biotek Instruments $\mathrm{GmbH}$, Bad Friedrichshall, Germany). The absorbance reader corrects the different filling levels to a light path length of $1 \mathrm{~cm}$. In this way, activity can be calculated according to Lambert-Beer's law. GPx activity was estimated with $50 \mu \mathrm{mol} / \mathrm{L} \mathrm{H}_{2} \mathrm{O}_{2}$ as substrate and expressed as $\mathrm{mU} / \mathrm{mg}$ protein for leukocytes and $\mathrm{mU} / \mathrm{ml}$ plasma, respectively. One unit (U) was defined as consumption of $1 \mu \mathrm{mol}$ nicotinamide adenine dinucleotide phosphate (NADPH) per minute.

\subsection{TrxR activity}

TrxR activity was estimated by the reduction of 5,5'-dithio-bis (2-nitrobenzoic acid) (DTNB) to 2-nitro-5-thiobenzoic acid (TNB) by NADPH [38]. Ten microliters of leukocyte lysate was mixed with $100-\mu \mathrm{l}$ reaction mixture containing $100 \mathrm{mmol} / \mathrm{L} \mathrm{KPi}, 2 \mathrm{mmol} / \mathrm{L}$ ethylenediaminetetraacetic acid (EDTA), pH 7.4, and $15 \mu \mathrm{l}$ DTNB ( $50 \mathrm{mmol} / \mathrm{L}$ in DMSO) in a 96-well plate. The reaction was started by adding $25 \mu \mathrm{l}$ of $2 \mathrm{mmol} / \mathrm{L}$ NADPH. TNB production was monitored in a plate reader (Synergy 2; Biotek Instruments $\mathrm{GmbH}$, Bad Friedrichshall, Germany) at $412 \mathrm{~nm}$ at $25^{\circ} \mathrm{C}$. TrxR-independent TNB formation, determined in the absence of $\mathrm{NADPH}$, was subtracted, and data were expressed as $\mathrm{mU} / \mathrm{mg}$ protein. One unit is defined as the consumption of $1 \mu \mathrm{mol} \mathrm{NADPH}$, i.e., production of $2 \mu \mathrm{mol}$ of TNB (extinction coefficient $=13.6(\mathrm{mmol} / \mathrm{L})^{-1} \cdot \mathrm{cm}^{-1}$ per $\mathrm{min}$.

\subsection{Myeloperoxidase activity}

Myeloperoxidase (MPO) activity of leukocyte homogenates was determined as previously described [39] with some modifications. Briefly, $40 \mu \mathrm{l}$ of eightfold-diluted leukocyte sample was added to $190 \mu \mathrm{l}$ reagent buffer $(0.1 \mathrm{~mol} / \mathrm{L}$ sodium citrate buffer, pH 5.5 containing $0.125 \%$ Triton X-100 and $0.8 \mathrm{mmol} / \mathrm{L}$ o-dianisidine dihydrochloride added from an $80-\mathrm{mmol} / \mathrm{L}$ stock solution in DMSO) into a 96-well plate. Each sample was measured twice, with and without the MPO inhibitor sodium azide $(0.01 \%)$. Reaction was started by injecting $10 \mu \mathrm{l}$ of $2 \mathrm{mmol} / \mathrm{L} \mathrm{H}_{2} \mathrm{O}_{2}$ (final concentration: 100 $\mu \mathrm{mol} / \mathrm{L}$ ) per well. Absorbance was measured using a microtiter plate absorbance reader (Synergy 2; Biotek Instruments $\mathrm{GmbH}$ ) at $460 \mathrm{~nm}$. Production of oxidized o-dianisidine is equivalent with $\mathrm{H}_{2} \mathrm{O}_{2}$ consumption and was determined using an extinction coefficient of $11.3(\mathrm{mmol} / \mathrm{L})^{-1} \cdot \mathrm{cm}^{-1}$ [40]. One unit (U) was defined as consumption of $1 \mu \mathrm{mol} \mathrm{H}_{2} \mathrm{O}_{2}$ per minute.

\subsection{Lysozyme activity}

The lysoplate assay was performed as described [41] with a final concentration of $50 \mathrm{mg}$ of lyophilized Micrococcus lysodeikticus in $100 \mathrm{ml}$ of $1 \%$ agarose in $0.15 \mathrm{~mol} / \mathrm{L}$ sodium phosphate buffer, $\mathrm{pH}$ 6.6. A total of $25 \mu \mathrm{l}$ of undiluted sample was transferred to filter paper positioned on the agar plate. The zones of lysis were measured after $18 \mathrm{~h}$ of incubation at $25^{\circ} \mathrm{C}$ using Quantity One software (BioRad, Munich, Germany). The values were converted to $\mu$ g of lysozyme per mg protein by reference to a standard curve.

\subsection{Plasma selenium level}

Selenium content of the plasma was measured fluorometrically as previously described [28].

\subsection{Statistical analysis}

Comparing two groups, significant differences were calculated by an unpaired Student's $t$ test. A $P$ value of $<.05$ was regarded as statistically significant. Fold-changes (FCs) are calculated as mean of selenium restricted/selenium adequate.

\section{Results}

3.1. Plasma selenium concentration and GPx activity as well as GPx and TrxR activity in splenic leukocytes were down-regulated by marginal selenium deficiency

Plasma selenium levels (Fig. 1A) and plasma GPx activity (Fig. 1B) mainly representing activity of GPx3 were drastically reduced upon feeding the selenium-poor diet. Together with liver and colon GPx activity measured previously in these mice [28], it is clear that feeding a diet containing half the estimated nutrient requirements of mice [30] already substantially reduces classical markers for the selenium status. In contrast, in leukocytes, the drop in GPx activity to $76 \%$ was less pronounced (Fig. 1C). Compared to the GPx activity in selenium-adequate colon (150 $\mathrm{mU} / \mathrm{mg}$ protein), leukocyte GPx activity was relatively high $(400 \mathrm{mU} / \mathrm{mg}$ protein), but still below the activity in the liver ( $750 \mathrm{mU} / \mathrm{mg}$ protein) [28]. Also, leukocytic TrxR activity was only marginally down-regulated to $88 \%$ by feeding a selenium-poor diet (Fig. 1D). Mean levels of TrxR activity were approximately $10 \mathrm{mU} / \mathrm{mg}$ protein, which is comparable to activities measured in selenium-adequate colon (authors' unpublished observations).

\subsection{Marginal selenium deficiency decreases the expression of a subset of selenoproteins in splenic leukocytes}

Microarray analysis revealed that 18 out of 24 murine selenoproteins are expressed in leukocytes (Table 2). Gpx3, Selv, Seln and the genes of the three DIO were not detectable in any dietary group. To validate the microarray data, all 18 selenoproteins were analyzed by qPCR. In both microarray analysis and qPCR, Sepw1, Gpx1, Selh and Sep15 were the most significantly down-regulated selenoprotein genes under selenium restriction. The decrease in Gpx4 was statistically significant when estimated by microarray analysis and close to significance in the qPCR assay. Selk, Selm and Selt were significantly down-regulated in qPCR analyses only. Gpx1 is the selenoprotein with the highest mRNA expression level in the leukocytes samples analyzed (Fig. S1A), followed by Gpx4, Sepx1, Sep15, Sepw1 and Sepp1. This selenoprotein expression pattern highly correlates with the published expression pattern for T-cells isolated from lymph node, spleen and thymus [42].

\subsection{Inflammatory response and heme biosynthesis are preferentially} affected by selenium restriction

According to microarray analysis, 16,866 transcripts were expressed twofold above the background in leukocytes from mice of different selenium status. Using the statistical criterion FDR with a cutoff of $<0.05$, only the expression of Sepw1 (FC: 0.66; FDR: 0.024) and Eif4e3 (FC: 0.83; FDR: 0.025) was significantly decreased under selenium restriction, which was confirmed by qPCR. Based on a less stringent statistical criterion, a $P$ value $<.05,1319$ genes were significantly changed, 762 were down-regulated under selenium restriction, while 557 were up-regulated.

Table 1

Primer sequences $\left(5^{\prime} \rightarrow 3^{\prime}\right)$

\begin{tabular}{|c|c|c|c|}
\hline Gene name & Acc. number & Primer sequence & Product \\
\hline Camp & NM_009921.1 & $\begin{array}{l}\text { fwd TATGTGGCAAGGCAGAGCGG } \\
\text { rev CTGTGCACCAGGCTCGTTACAG }\end{array}$ & 139 bp \\
\hline Ccna2 & NM_009828.2 & $\begin{array}{l}\text { fwd GTTTGATAGATGCTGACCCGTACC } \\
\text { rev CCAATGACTCAGGCCAGCTC }\end{array}$ & $110 \mathrm{bp}$ \\
\hline Chi3l3 & NM_009892.1 & $\begin{array}{l}\text { fwd ATGGCCTCAACCTGGACTGG } \\
\text { rev AGCCTTGGAATGTCTTTCTCCACA }\end{array}$ & 136 bp \\
\hline Ctsg & NM_007800.1 & $\begin{array}{l}\text { fwd TGAGGCAGGGAAGATCATTGGA } \\
\text { rev CACCAGAAACCCTCCACAAGCA }\end{array}$ & 114 bp \\
\hline Fech & NM_007998.4 & $\begin{array}{l}\text { fwd TCCAGAGGAGAAGAGAAGCGAG } \\
\text { rev GTACTGGACCAACCTTGGACTG }\end{array}$ & $181 \mathrm{bp}$ \\
\hline Hmbs & NM_001110251.1 & $\begin{array}{l}\text { fwd AAAGATGGGCAACTGTACCTGAC } \\
\text { rev TTACGGGCAGTGATTCCAACCAG }\end{array}$ & $150 \mathrm{bp}$ \\
\hline Ltf & NM_008522.3 & $\begin{array}{l}\text { fwd TCTCTGTGCCCTGTGTATTGGT } \\
\text { rev TTCTCAGCCAGACACCTTAAAGCC }\end{array}$ & 107 bp \\
\hline Lyz1/2 & NM_013590.3 & $\begin{array}{l}\text { fwd TTCGAGCATGGGTGGCATGG } \\
\text { rev GGCTGCAGTAGAAGCACACC }\end{array}$ & $100 \mathrm{bp}$ \\
\hline Mpo & NM_010824.1 & $\begin{array}{l}\text { fwd GGCCTCCCAGGATACAATGC } \\
\text { rev ACACCGCCCATCCAGATGTC }\end{array}$ & $157 \mathrm{bp}$ \\
\hline Ngp & NM_008694.2 & $\begin{array}{l}\text { fwd AGAGACAGCCTAAAGACTGCGAC } \\
\text { rev TTCTTGGGTATCCTCTCGACTGC }\end{array}$ & $136 \mathrm{bp}$ \\
\hline $\operatorname{Prdx} 2$ & NM_011563.5 & $\begin{array}{l}\text { fwd GGACTACAGAGGGAAGTACGTGG } \\
\text { rev GCAGCCTAGCTTTCGGAAGTC }\end{array}$ & 117 bp \\
\hline S100A8 & NM_013650.2 & $\begin{array}{l}\text { fwd TGAGTGTCCTCAGTTTGTGCAG } \\
\text { rev CTACTCCTTGTGGCTGTCTTTGTG }\end{array}$ & $151 \mathrm{bp}$ \\
\hline \multicolumn{4}{|l|}{ Reference genes: } \\
\hline Hprt1 & NM_013556 & $\begin{array}{l}\text { fwd GCAGTCCCAGCGTCGTG } \\
\text { rev GGCCTCCCATCTCCTTCAT }\end{array}$ & $168 \mathrm{bp}$ \\
\hline Rpl13a & NM_009438 & $\begin{array}{l}\text { fwd GTTCGGCTGAAGCCTACCAG } \\
\text { rev TTCCGTAACCTCAAGATCTGCT }\end{array}$ & 157 bp \\
\hline
\end{tabular}



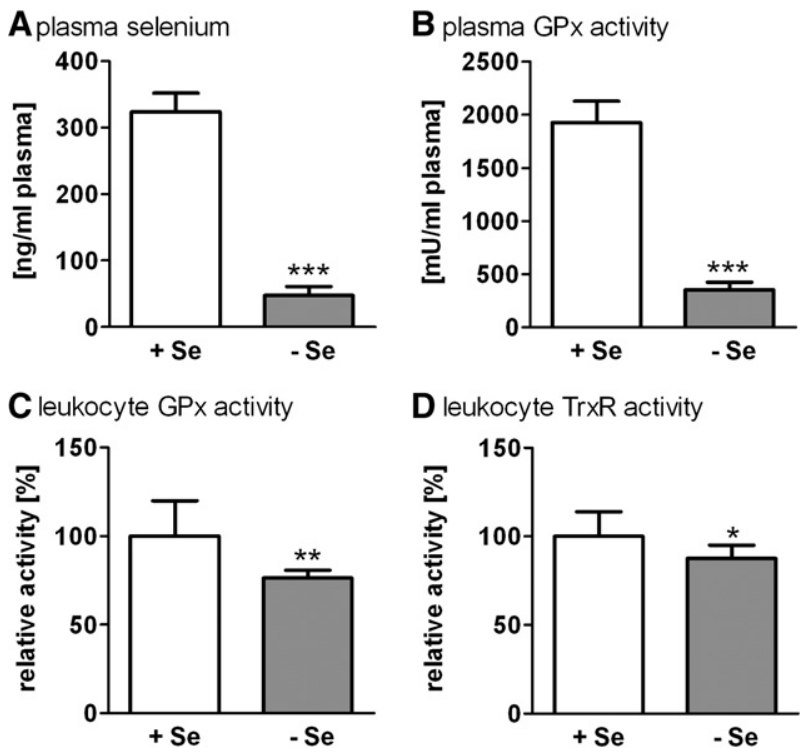

Fig. 1. Plasma selenium concentration (A), GPx activity in plasma (B) and splenic leukocytes (C) and TrxR activity in splenic leukocytes (D) decrease by feeding a marginal selenium-deficient diet. + Se: mice fed a selenium-adequate diet $(0.15 \mathrm{mg} / \mathrm{kg}$ diet); -Se: mice fed a marginal selenium-deficient diet $(0.086 \mathrm{mg} / \mathrm{kg}$ diet $)$. Values are means of 12 animals per group for assays measured in plasma and 10 animals for GPX and TrxR activities (with + Se set to 1 ) measured in triplicate \pm S.D. ${ }^{*} P<.05$, ${ }^{* *} P<.01$ and $* * * P<.001 \mathrm{vs}$. the selenium-adequate feeding using Student's $t$ test.

A subgroup of 83 genes (Table 3) was selected from these corresponding to genes with a $P$ value $<.05$ and an absolute $\mathrm{FC}>1.4$ and classified at the basis of gene ontology terms (see "Methods and materials"). Out of these 83 genes, only one gene was up-regulated on the selenium-poor diet; the remainder were down-regulated. The likely explanation for this phenomenon is that, in the underlying data set, absolute FCs of down-regulated genes are higher than those of upregulated genes. From the selenoproteins, only Sepw1 and Gpx1 showed up in the list because the FCs of the others were too small to fall into the selected range. The classification revealed a consistent down-regulation under selenium restriction of genes involved in inflammatory response, cell cycle, transport, heme biosynthesis and DNA binding (Table 3). The largest group was inflammatory response including $25.3 \%$ of all genes, followed by cell cycle with $14.5 \%$. Pathway analysis of the whole data set based on a $P$ value $<.05$ and an absolute FC $>1.2$ using PathVisio partially confirmed these results, with the heme biosynthesis pathway being the most strikingly affected with a $z$-score of 10 . The whole pathway consists of nine proteins, and gene expression of six of them was significantly reduced under selenium restriction (Fig. S2). Affected genes were Alas2, Hmbs, Cpox and Fech (listed in Table 3) and, additionally, uroporphyrinogen decarboxylase (Urod, FC: $0.72 ; P$ value $=.014$ ) and protoporphyrinogen oxidase (Ppox, FC: 0.81; $P$ value $=.013$ ). The heme biosynthesis pathway was followed by the pathways for DNA replication (zscore $=8$ ) and cell cycle $(z$-score $=7.9)$. According to pathway analysis, pathways representative for inflammation were not affected by the selenium status.

Fold-changes of genes for core enzymes of the heme biosynthesis pathway, Hmbs and Fech, and of inflammation-related genes (Mpo, Ltf, Ctsg, S100a8, Camp, Ngp, Prdx2, Lyz2 and Chi3l3) were confirmed by qPCR. As a representative of the cell cycle group, cyclin A2 was chosen for qPCR analysis (Table 3). Representative genes linked to inflammation were generally expressed higher than other genes analyzed in leukocytes; the highest expression levels were observed for Ngp and S100A8 (Fig. S1B). Mutual confirmation of gene expression data by two techniques demonstrated the validity of the data.

\subsection{Reduced mRNA expression correlated with a decreased activity of MPO and lysozyme}

To test whether the change in mRNA levels influences functionality, enzyme activity was tested for MPO and lysozyme. In both cases, the reduced mRNA expression in mice fed the selenium-restricted diet was found to be correlated with lower enzymatic activity (Fig. 2). This effect did not reach statistical significance, probably due to the high variance of the enzyme activities in animals of the seleniumadequate group.

\subsection{Nuclear factor- $\kappa B$ target gene expression is repressed under marginal selenium deficiency}

For further analysis of the classified genes, a common transcription factor was searched to explain their selenium-dependent regulation. Twelve of the classified genes (Table 3, gene names in

Table 2

Leukocyte selenoprotein genes responding to selenium supply as measured by microarray analysis and qPCR

\begin{tabular}{|c|c|c|c|c|c|c|}
\hline \multirow[t]{2}{*}{ Gene name } & \multirow[t]{2}{*}{ Description } & \multirow[t]{2}{*}{ Acc. number } & \multicolumn{2}{|c|}{ Microarray $(n=12)$} & \multicolumn{2}{|c|}{$\mathrm{qPCR}(n=12)$} \\
\hline & & & $P$ value & FC & $P$ value & FC \\
\hline Sepw1 & Selenoprotein W & NM_009156 & $2.66 \times 10^{-6}$ & 0.66 & $9.11 \times 10^{-8}$ & 0.68 \\
\hline Gpx1 & Glutathione peroxidase 1 & NM_008160 & .000081 & 0.63 & .006 & 0.6 \\
\hline Selh (2700094K13Rik) & Selenoprotein $\mathrm{H}$ & NM_001037279 & .0005 & 0.81 & $2.34 \times 10^{-6}$ & 0.83 \\
\hline Sep15 & Selenoprotein 15 & NM_053102 & .007 & 0.85 & .006 & 0.55 \\
\hline Gpx4 & Glutathione peroxidase 4 & NM_001037741 & .024 & 0.87 & .055 & 0.87 \\
\hline Sepp1 & Selenoprotein P & NM_001042614 & .054 & 0.84 & .185 & 0.9 \\
\hline Gpx2 & Glutathione peroxidase 2 & NM_030677 & .068 & 1.14 & .484 & 0.95 \\
\hline Sepx1 (MsrB1) & Selenoprotein X & NM_013759 & .227 & 0.86 & .093 & 0.75 \\
\hline Seli (D5Wsu178e) & Selenoprotein I & NM_027652 & .377 & 0.96 & .191 & 0.91 \\
\hline Selt (2810407C02Rik) & Selenoprotein $\mathrm{T}$ & NM_001040396 & .399 & 0.94 & .006 & 0.86 \\
\hline Txnrd1 & Thioredoxin reductase 1 & NM_001042523 & .598 & 1.03 & .184 & 0.93 \\
\hline Sephs2 & Selenophosphate synthetase 2 & NM_009266 & 662 & 0.97 & .368 & 0.95 \\
\hline Txnrd2 & Thioredoxin reductase 2 & NM_013711 & 680 & 0.98 & .056 & 0.83 \\
\hline Sels (H47) & Selenoprotein S & NM_024439 & 693 & 1.02 & .093 & 0.89 \\
\hline Txnrd3 & Thioredoxin reductase 3 & NM_153162 & 695 & 1.03 & .277 & 0.93 \\
\hline Selk & Selenoprotein K & NM_019979 & .751 & 1.02 & .005 & 0.46 \\
\hline Selm & Selenoprotein M & NM_053267 & .845 & 0.99 & .007 & 0.67 \\
\hline Selo (1300018J18Rik) & Selenoprotein 0 & NM_027905 & .979 & 1.00 & .868 & 1.01 \\
\hline
\end{tabular}

Genes were sorted by the $P$ value measured in microarray analysis. $\mathrm{FC}=$ fold change in relation to the adequate diet. 
Table 3

Classification of 83 genes differentially expressed under marginal selenium deficiency

\begin{tabular}{|c|c|c|c|c|c|c|c|}
\hline \multirow[t]{2}{*}{ Gene name } & \multirow[t]{2}{*}{ Description } & \multirow[t]{2}{*}{ Acc. number } & \multirow[t]{2}{*}{ Entrez_ID } & \multicolumn{2}{|l|}{ Microarray } & \multicolumn{2}{|l|}{ PCR } \\
\hline & & & & $P$ value & $\mathrm{FC}$ & $P$ value & FC \\
\hline \multicolumn{8}{|c|}{ Selenoproteins $(2.4 \%)$} \\
\hline Gpx1 & Glutathione peroxidase 1 & NM_008160 & 14775 & .000081 & 0.63 & .0057 & 0.60 \\
\hline Sepw1 & Selenoprotein $\mathrm{W}$, muscle 1 & NM_009156 & 20364 & $2.66 \times 10^{-6}$ & 0.66 & $9.11 \times 10^{-8}$ & 0.68 \\
\hline \multicolumn{8}{|c|}{ Inflammatory response $(25.3 \%)$} \\
\hline Anxa1 & Annexin A1 & NM_010730 & 16952 & .009 & 0.57 & & \\
\hline C3 & Complement component 3 & NM_009778 & 12266 & .035 & 0.65 & & \\
\hline Camp & Cathelicidin antimicrobial peptide & NM_009921 & 12796 & .010 & 0.47 & .030 & 0.40 \\
\hline Chi313 & Chitinase 3-like 3 & NM_009892 & 12655 & .014 & 0.52 & .067 & 0.43 \\
\hline Chi314 & Chitinase 3 -like 4 & NM_145126 & 104183 & .023 & 0.60 & & \\
\hline Ctse & Cathepsin E & NM_007799 & 13034 & .009 & 0.59 & & \\
\hline Ctsg & Cathepsin G & NM_007800 & 13035 & .005 & 0.64 & .013 & 0.44 \\
\hline H2-DMb1 & Histocompatibility 2, class II, locus Mb1 & NM_010387 & 14999 & .0004 & 1.40 & & \\
\hline Ifitm6 & Interferon induced transmembrane protein 6 & NM_001033632 & 213002 & .017 & 0.64 & & \\
\hline Ltf & Lactotransferrin & NM_008522 & 17002 & .005 & 0.44 & .038 & 0.38 \\
\hline Lyz2 & Lysozyme & NM_017372 & 17105 & .014 & 0.63 & .082 & 0.66 \\
\hline Lzp-s & P lysozyme structural & NM_013590 & 17110 & .030 & 0.66 & & \\
\hline March8 & Membrane-associated ring finger ( $\mathrm{C} 3 \mathrm{HC} 4) 8$ & NM_027920 & 71779 & .005 & 0.62 & & \\
\hline Mpo & Myeloperoxidase & NM_010824 & 17523 & .004 & 0.45 & .024 & 0.48 \\
\hline Ngp & Neutrophilic granule protein & NM_008694 & 18054 & .013 & 0.49 & .059 & 0.47 \\
\hline $\operatorname{Prd} 2$ & Peroxiredoxin 2 & NM_011563 & 21672 & .012 & 0.68 & .009 & 0.46 \\
\hline Rsad2 & Radical S-adenosyl methionine domain containing 2 & NM_021384 & 58185 & .011 & 0.64 & & \\
\hline S100a8 & S100 calcium binding protein A8 (calgranulin A) & NM_013650 & 20201 & .009 & 0.47 & .145 & 0.57 \\
\hline S100a9 & S100 calcium binding protein A9 (calgranulin B) & NM_009114 & 20202 & .044 & 0.65 & & \\
\hline Sphk1 & Sphingosine kinase 1 & NM_025367 & 20698 & .023 & 0.69 & & \\
\hline Wdnm1-like & Westmead DMBA8 nonmetastatic cDNA 1 like & NM_183249 & 66107 & .035 & 0.58 & & \\
\hline Cell cycle/prol & ion $(14.5 \%)$ & & & & & & \\
\hline Birc5 & Baculoviral IAP repeat-containing 5 (survivin) & NM_001012273 & 11799 & .010 & 0.61 & & \\
\hline Ccna2 & Cyclin A2 & NM_009828 & 12428 & .003 & 0.60 & .037 & 0.59 \\
\hline Ccnb2 & Cyclin B2 & NM_007630 & 12442 & .020 & 0.69 & & \\
\hline Cdca3 & Cell division cycle associated 3 & NM_013538 & 14793 & .015 & 0.68 & & \\
\hline Cdca8 & Cell division cycle associated 8 & NM_026560 & 52276 & .004 & 0.67 & & \\
\hline Cdkn3 & Cyclin-dependent kinase inhibitor 3 & ВС049694 & 72391 & .048 & 0.71 & & \\
\hline Cks2 & CDC28 protein kinase regulatory subunit 2 & NM_025415 & 66197 & .010 & 0.68 & & \\
\hline Gmnn & Geminin & NM_020567 & 57441 & .014 & 0.68 & & \\
\hline Mki67 & Ki-67 & X82786 & 17345 & .003 & 0.60 & & \\
\hline Plk1 & Polo-like kinase 1 & NM_011121 & 18817 & .001 & 0.68 & & \\
\hline Rrm2 & Ribonucleotide reductase M2 & NM_009104 & 20135 & .015 & 0.65 & & \\
\hline Tyms & Thymidylate synthase & NM_021288 & 22171 & .008 & 0.66 & & \\
\hline Transport (13. & & & & & & & \\
\hline Ank1 & Ankyrin 1 , erythroid & NM_031158 & 11733 & .005 & 0.59 & & \\
\hline Aqp1 & Aquaporin 1 & NM_007472 & 11826 & .006 & 0.55 & & \\
\hline Rhd & Rh blood group, D antigen & NM_011270 & 19746 & .003 & 0.49 & & \\
\hline Slc16a1 & Solute carrier family 16 , member 1 & NM_009196 & 20501 & .006 & 0.69 & & \\
\hline Slc25a37 & Solute carrier family 25 , member 37 & NM_026331 & 67712 & .004 & 0.62 & & \\
\hline Slc38a5 & Solute carrier family 38 , member 5 & NM_172479 & 209837 & .024 & 0.64 & & \\
\hline Slc43a1 & Solute carrier family 43 , member 1 & ВC053747 & 72401 & .040 & 0.71 & & \\
\hline Slc43a3 & Solute carrier family 43 , member 3 & NM_021398 & 58207 & .007 & 0.71 & & \\
\hline Slc4a1 & Solute carrier family 4 (anion exchanger), member 1 & NM_011403 & 20533 & .002 & 0.48 & & \\
\hline Slc6a9 & Solute carrier family 6 , member 9 & NM_008135 & 14664 & .003 & 0.68 & & \\
\hline Tspo2 & Benzodiazapine receptor, peripheral-like 1 & NM_027292 & 70026 & .004 & 0.68 & & \\
\hline Heme biosynt & hemopoiesis (12\%) & & & & & & \\
\hline Alas2 & Aminolevulinic acid synthase 2 , erythroid & NM_009653 & 11656 & .042 & 0.70 & & \\
\hline Blvrb & Biliverdin reductase $\mathrm{B}$ & NM_144923 & 233016 & .035 & 0.71 & & \\
\hline Cpox & Coproporphyrinogen oxidase & NM_007757 & 12892 & .023 & 0.64 & & \\
\hline Eraf & Erythroid associated factor & NM_133245 & 170812 & .019 & 0.56 & & \\
\hline Fech & Ferrochelatase & NM_007998 & 14151 & .017 & 0.68 & .077 & 0.57 \\
\hline Hba-a1 & Alpha-globin & M10466 & 15122 & .044 & 0.65 & & \\
\hline Hbb-b1 & Hemoglobin, beta adult major chain & NM_008220 & 15129 & .012 & 0.58 & & \\
\hline Hebp1 & Heme binding protein 1 & NM_013546 & 15199 & .035 & 0.71 & & \\
\hline Hmbs & Hydroxymethylbilane synthase & NM_013551 & 15288 & .011 & 0.59 & .028 & 0.50 \\
\hline Tal1 & T-cell acute lymphocytic leukemia 1 & NM_011527 & 21349 & .043 & 0.65 & & \\
\hline DNA binding ( & & & & & & & \\
\hline Gfi1b & Growth factor independent $1 \mathrm{~B}$ & NM_008114 & 14582 & .026 & 0.69 & & \\
\hline H2afj & H2A histone family, member J & NM_177688 & 232440 & .006 & 0.67 & & \\
\hline Hist1h1b & Histone cluster $1, \mathrm{H} 1 \mathrm{~b}$ & NM_020034 & 56702 & .014 & 0.70 & & \\
\hline Hist1h2aa & Histone cluster $1, \mathrm{H} 2 \mathrm{aa}$ & NM_175658 & 319163 & .006 & 0.64 & & \\
\hline Hist1h2af & Histone cluster $1, \mathrm{H} 2 \mathrm{af}$ & NM_175661 & 319173 & .006 & 0.65 & & \\
\hline Hist1h4d & Histone cluster 1, H4d & NM_175654 & 319156 & .004 & 0.67 & & \\
\hline Hist2h2ab & Histone cluster 2, H2ab & NM_178213.3 & - & .012 & 0.68 & & \\
\hline Hist3h2a & Histone cluster $3, \mathrm{H} 2 \mathrm{a}$ & NM_178218 & 319162 & .004 & 0.70 & & \\
\hline Hmgb2 & High mobility group box 2 & NM_008252 & 97165 & .001 & 0.64 & & \\
\hline $\begin{array}{l}\text { Hist1h2ao } \\
\text { Others }(20.5 \%\end{array}$ & Similar to histone $2 \mathrm{a}$ & ВС090402 & 665433 & .008 & 0.62 & & \\
\hline
\end{tabular}




\begin{tabular}{|c|c|c|c|c|c|c|c|}
\hline \multirow[t]{2}{*}{ Gene name } & \multirow[t]{2}{*}{ Description } & \multirow[t]{2}{*}{ Acc. number } & \multirow[t]{2}{*}{ Entrez_ID } & \multicolumn{2}{|c|}{ Microarray } & \multicolumn{2}{|l|}{ PCR } \\
\hline & & & & $P$ value & $\mathrm{FC}$ & $P$ value & FC \\
\hline Apol2 & Adult male corpora quadrigemina & AK046043 & 239552 & .038 & 0.70 & & \\
\hline Butr1 & Butyrophilin related 1 & NM_138678 & 192194 & .021 & 0.69 & & \\
\hline C1qdc2 & C1q domain containing 2 & NM_026125 & 67389 & .009 & 0.60 & & \\
\hline Car2 & Carbonic anhydrase 2 & NM_009801 & 12349 & .006 & 0.51 & & \\
\hline Ckap4 & Cytoskeleton-associated protein 4 & NM_175451 & 216197 & .022 & 0.68 & & \\
\hline Clec5a & C-type lectin domain family 5 , member a & NM_001038604 & 23845 & .036 & 0.69 & & \\
\hline Epor & Erythropoietin receptor & NM_010149 & 13857 & .008 & 0.63 & & \\
\hline Ermap & Erythroblast membrane-associated protein & NM_013848 & 27028 & .027 & 0.66 & & \\
\hline Hemgn & Hemogen & NM_053149 & 93966 & .036 & 0.58 & & \\
\hline $\mathrm{Kel}$ & Kell blood group & NM_032540 & 23925 & .010 & 0.63 & & \\
\hline Metap2 & Methionine aminopeptidase 2 & NM_019648 & 56307 & .005 & 0.71 & & \\
\hline mICA & Murine inhibitor of carbonic anhydrase & NM_027918 & 71775 & .020 & 0.68 & & \\
\hline Npsr1 & Neuropeptide $S$ receptor 1 & NM_175678 & 319239 & .009 & 0.67 & & \\
\hline St3gal5 & ST3 beta-galactoside alpha-2,3-sialyltransferase 5 & NM_011375 & 20454 & .021 & 0.65 & & \\
\hline Stmn1 & Stathmin 1 & NM_019641 & 16765 & .003 & 0.68 & & \\
\hline Trim10 & Tripartite motif protein 10 & NM_011280 & 19824 & .006 & 0.69 & & \\
\hline Tspan33 & Tetraspanin 33 & NM_146173 & 232670 & .014 & 0.64 & & \\
\hline
\end{tabular}

Genes were selected according to the following criterion: $P$ value $<.05$ and absolute $\mathrm{FC}>1.4$. Genes printed in italic are known NF- $\kappa \mathrm{B}$ target genes.

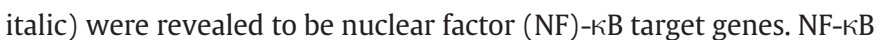
is a key player in inflammation and known to be influenced by selenium. Therefore, the complete microarray expression data set was analyzed for NF- $\kappa B$ target genes. Out of more than 100 genes for known NF- $\kappa B$ targets (listed in Ref. [43] and under www.nf-kb.org) expressed in the leukocyte data set, 40 were significantly regulated by the selenium status (Table 4). Thirty-one genes were downregulated under marginal selenium deficiency, which account for 77.5\%. In addition, the NF- KB target gene Sels [44] was unaffected by the selenium status in the microarray, but was also down-regulated in the qPCR analysis (Table 2).

\section{Discussion}

Feeding a moderate selenium-deficient diet to mice resulted in a consistent down-regulation of the plasma selenium level and GPX activity. As previously reported, GPx activity was also strongly reduced in the liver and colon of these animals [28]. In addition, GPx (Fig. 1C) and TrxR (Fig. 1D) activity was lower in splenic leukocytes, but the fall in activity was less than that in other tissues, which was already shown for $\mathrm{CD}^{+}{ }^{+}$T-cells isolated from murine spleen [26]. Accordingly, FCs of selenoprotein mRNA levels in leukocytes were smaller than in the colon (see Ref. [28]), but statistically significant, and the affected selenoproteins Sepw1, Gpx1 and Selh were the three most selenium-sensitive selenoproteins in both colon and leukocytes [28] (Table 2). In addition, both microarray and qPCR analyses showed that Sep 15 expression was highly affected by selenium intake in leukocytes. In comparison, down-regulation of Sep15 by selenium restriction was less in the colon [28]. Granulocytes, which represent $18 \%$ of the analyzed leukocytes, may substantially contribute to the stronger down-regulation in selenium-poor leukocytes since Sep15 is the major selenoprotein expressed in this subpopulation [45] and was found to be also highly expressed in leukocytes analyzed here (Fig. S1). Although expression of selenoproteins $\mathrm{K}, \mathrm{M}$ and $\mathrm{T}$ did not appear to be significantly altered in the microarray analysis, all three genes were significantly downregulated in marginal selenium deficiency when assessed by qPCR, with Selk showing the largest FC of all selenoproteins (Table 2). Interestingly, microarray analysis of human lymphocytes after supplementation with $100 \mu \mathrm{g}$ sodium selenite daily for 6 weeks resulted in up-regulated mRNA expression of both Selk and Sep15 [29]. Thus, it appears that, in leukocytes, mRNA expression of Sepw1, Gpx1, Selh, Selk and Sep15 is sensitive to selenium supply.
The response of selenoprotein expression to selenium intake is known to be tissue specific $[46,47]$. In a recent study, a panel of molecular biomarkers was analyzed by multiple regression analysis against selenium level and GPx activity in liver and kidney of rats [48]. Hepatic mRNA expression of Gpx1, Sepw1, Selh, Selk and Sep15 was the most significantly correlated with both the selenium level and GPx activity, whereas the ranking in the kidney was Sepw1, Selk, Selh, Gpx1 and Gpx3 against the selenium level and Sepw1, Gpx1, Selh, Txnrd1 and Selk against GPx activity. Taking these data together with the present results suggests that Sepw1, Gpx1 and Selh represent the most sensitive biomarkers for a moderate selenium deficiency that are common to several tissues, at least in rodents.
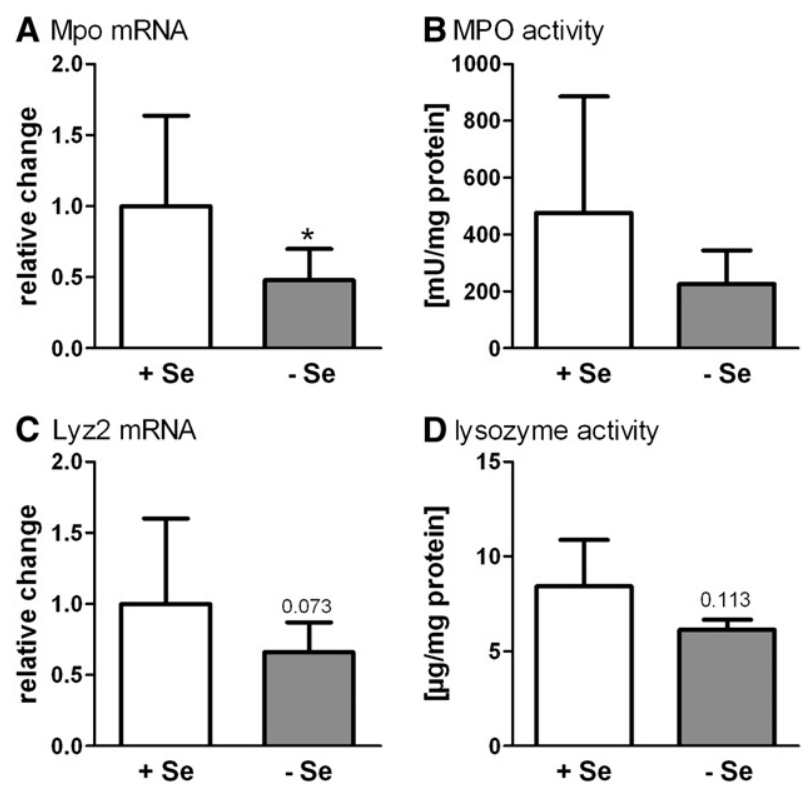

Fig. 2. mRNA expression and activity of MPO and lysozyme (Lyz2) are down-regulated in response to selenium restriction in splenic leukocytes. mRNA expression of Mpo (A) and Lyz2 (C) was measured in 12 animals per group, while MPO activity (B) and the amount of active lysozyme (D) were measured in five animals per group. Gene expression was analyzed by qPCR and normalized to the mean of the reference genes Hprt1 and Rpl13a. +Se: mice fed a selenium-adequate diet $(0.15 \mathrm{mg} / \mathrm{kg}$ diet $) ;-$ Se: mice fed a marginal selenium-deficient diet $(0.086 \mathrm{mg} / \mathrm{kg}$ diet $)$. Values are means \pm S.D. $* P<.05$ vs. selenium-adequate feeding using Student's $t$ test. 
Table 4

NF- $\kappa$ B target genes differentially expressed in splenic leukocytes

\begin{tabular}{|c|c|c|c|c|}
\hline \multirow{2}{*}{$\begin{array}{l}\text { Gene } \\
\text { name }\end{array}$} & \multirow[t]{2}{*}{ Description } & \multirow[t]{2}{*}{ Acc. number } & \multicolumn{2}{|c|}{ Microarray } \\
\hline & & & $P$ value & FC \\
\hline \multicolumn{5}{|c|}{ Down-regulated (77.5\%) } \\
\hline Abcb4 & ATP-binding cassette, sub-family B & NM_008830 & .007 & 0.72 \\
\hline Birc5 & $\begin{array}{l}\text { Baculoviral IAP repeat-containing } \\
5 \text { (survivin) }\end{array}$ & NM_001012273 & .010 & 0.61 \\
\hline Brca2 & Breast cancer 2 & NM_009765 & .015 & 0.80 \\
\hline C3 & Complement component 3 & NM_009778 & .035 & 0.65 \\
\hline Camp & Cathelicidin antimicrobial peptide & NM_009921 & .010 & 0.47 \\
\hline Ccl9 & Chemokine (C-C motif) ligand 9 & NM_011338 & .045 & 0.81 \\
\hline Ccnb2 & Cyclin B2 & NM_007630 & .020 & 0.69 \\
\hline Cd44 & CD44 antigen & NM_009851 & .021 & 0.85 \\
\hline Cdk6 & Cyclin-dependent kinase 6 & AK030810 & .014 & 0.83 \\
\hline Cks1b & CDC28 protein kinase $1 \mathrm{~b}$ & NM_016904 & .028 & 0.76 \\
\hline Ctsb & Cathepsin B & NM_007798 & .003 & 0.79 \\
\hline G6pdx & $\begin{array}{l}\text { Glucose-6-phosphate dehydrogenase } \\
\text { X-linked }\end{array}$ & NM_008062 & .043 & 0.81 \\
\hline Gclc & $\begin{array}{l}\text { Glutamate-cysteine ligase, } \\
\text { catalytic subunit }\end{array}$ & NM_010295 & .006 & 0.78 \\
\hline Hmgb1 & High mobility group box 1 & ВС064790 & .014 & 0.87 \\
\hline Hmgb2 & High mobility group box 2 & NM_008252 & .001 & 0.64 \\
\hline Hsp90aa1 & $\begin{array}{l}\text { Heat shock protein 90kDa } \\
\text { alpha (cytosolic) }\end{array}$ & NM_010480 & .015 & 0.81 \\
\hline Kel & Kell blood group & NM_032540 & .010 & 0.63 \\
\hline Lcn2 & Lipocalin 2 & NM_008491 & .041 & 0.73 \\
\hline Ltf & Lactotransferrin & NM_008522 & .005 & 0.44 \\
\hline Lyz2 & Lysozyme & NM_017372 & .014 & 0.63 \\
\hline Myb & Myeloblastosis oncogene & NM_010848 & .028 & 0.83 \\
\hline Pgk1 & Phosphoglycerate kinase 1 & NM_008828 & .009 & 0.88 \\
\hline Pigf & $\begin{array}{l}\text { Phosphatidylinositol glycan anchor } \\
\text { biosynthesis, class F }\end{array}$ & NM_008838 & .031 & 0.95 \\
\hline Plk1 & Polo-like kinase 1 & NM_011121 & .001 & 0.68 \\
\hline Ppih & Peptidyl prolyl isomerase $\mathrm{H}$ & NM_028677 & .045 & 0.90 \\
\hline Prdx2 & Peroxiredoxin 2 & NM_011563 & .012 & 0.68 \\
\hline S100a8 & $\begin{array}{l}\text { S100 calcium binding protein } \\
\text { A8 (calgranulin A) }\end{array}$ & NM_013650 & .009 & 0.47 \\
\hline S100a9 & $\begin{array}{l}\text { S100 calcium binding protein } \\
\text { A9 (calgranulin B) }\end{array}$ & NM_009114 & .044 & 0.65 \\
\hline Slc16a1 & $\begin{array}{l}\text { Solute carrier family } 16 \\
\text { (monocarboxylic acid transporters), } \\
\text { member } 1\end{array}$ & NM_009196 & .006 & 0.69 \\
\hline Top2a & Topoisomerase (DNA) II alpha & NM_011623 & .014 & 0.82 \\
\hline Vcam1 & Vascular cell adhesion molecule 1 & NM_011693 & .009 & 0.75 \\
\hline \multicolumn{5}{|c|}{ Up-regulated (22.5\%) } \\
\hline Adora2a & Adenosine A2a receptor & BC110692 & .049 & 1.10 \\
\hline Afp & Alpha fetoprotein & NM_007423 & .001 & 1.17 \\
\hline Ahctf1 & AT hook containing transcription factor 1 & NM_026375 & .040 & 1.17 \\
\hline Egr1 & Early growth response 1 & NM_007913 & .034 & 1.17 \\
\hline Fos & FBJ osteosarcoma oncogene & NM_010234 & .035 & 1.27 \\
\hline Hmgn1 & $\begin{array}{l}\text { High mobility group nucleosomal } \\
\text { binding domain } 1\end{array}$ & NM_008251 & .041 & 1.21 \\
\hline Nfkb2 & $\begin{array}{l}\text { Nuclear factor of kappa light } \\
\text { polypeptide gene enhancer in B-cells } 2\end{array}$ & NM_019408 & .019 & 1.16 \\
\hline Pik3ca & $\begin{array}{l}\text { Phosphatidylinositol 3-kinase, } \\
\text { catalytic, alpha polypeptide }\end{array}$ & АК029399 & .024 & 1.16 \\
\hline Rag1 & Recombination activating gene 1 & NM_009019 & .049 & 1.21 \\
\hline
\end{tabular}

Selenium supplementation in the SELGEN study among others resulted in an up-regulation of the protein biosynthesis network and translation-elongation termination pathways [29]. In the present study, genes for ribosomal proteins, translation elongation and translation initiation factors were mostly down-regulated by moderate selenium deficiency, which reflects their up-regulation upon selenium supplementation in the SELGEN study (Supplementary Table S2). These pathways did not show up in selenium-regulated groups here collected by strict restrictions (Table 3). More interestingly, immune T-cell receptor signaling was up-regulated by selenium in human lymphocytes [29], correlating with the downregulation of the inflammatory response in the present murine study (Table 3). Therefore, a more detailed comparison of significantly regulated genes in the human and the murine study was performed.
mRNA of Ltf (FC: 1.3; $P$ value=.0035), Anxa1 (FC: 1.09; $P$ value $=.041$ ), S100a8 (FC: 1.22; $P$ value $=.034$ ) and Camp (FC: 1.29; $P$ value $=.0013$ ) was up-regulated with selenium supplementation in humans [29] and down-regulated in moderate selenium deficiency in mice (Table 3). Thus, changes observed in the murine data set may also be relevant for humans.

Further pathways strikingly affected by the selenium status are heme biosynthesis and inflammatory response (Table 3). All genes linked to inflammation and confirmed by qPCR were involved in host defense and inflammatory response (Supplementary Table S1). MPO, which is exclusively expressed in neutrophiles and monocytes and for which the heme center of the enzyme is indispensable [49], contributes substantially to the antimicrobial system by generating reactive oxidants like $\mathrm{HOCl}$ and radical species [50]. In human neutrophils, MPO levels account for $2 \%-5 \%$ of total cellular protein [51], which explains the need of a high heme biosynthesis rate. Down-regulation of Mpo expression in selenium-poor leukocytes was linked to reduced heme biosynthesis and to reduced mRNA expression of the nonheme iron-binding protein lactotransferrin (Table 3). We speculate that these data reflect a link between selenium intake and iron metabolism.

MPO-derived oxidants not only are functional in antimicrobial and cytotoxic effects, but also are involved in signaling and the modulation of the immune response. $\mathrm{HOCl}$ has been reported to activate NF- $\kappa B$ [52], which might explain the inhibition of NF- $\kappa B$ target gene expression (Table 4) in parallel to the reduction of MPO activity (Fig. 2) under selenium restriction. However, in contrast to this first study, subsequent studies revealed that most of the $\mathrm{HOCl}-$ derived chloramines act as NF- $\kappa$ B inhibitors (reviewed in Ref. [53]). Also, the impact of the selenium status on the activity of the NF- $\kappa B$ pathway is ambivalent. NF- $\kappa B$ activation is inhibited by selenium supplementation as a result of an increased expression of GPX isoenzymes [54] or by direct overexpression of GPx1 [55] or GPx4 [56]. As often not expected, high doses of selenium also promote prooxidant effects, which are mostly attributed to selenium deficiency. Until today, the redox regulation of NF- $\kappa B$ is still a complex issue which is still controversially discussed $[57,58]$. Consistent downregulation of NF- $\kappa B$ targets shown here suggests an inhibition of the NF- $\kappa$ B pathway under moderate selenium deficiency.

Down-regulation of inflammation-dependent genes and NF- $\kappa B$ targets under marginal selenium deficiency would result in a reduced capability to deal with infections, which coincidences with results obtained in severe selenium deficiency mouse models. For example, the response of splenic natural killer cells to Listeria monocytogenes infection was significantly reduced in severe selenium deficiency compared to selenium-adequate mice [59]. Seleniumsupplemented $\mathrm{CD} 4^{+} \mathrm{T}$-cells had a higher antigen-specific response and T-cell receptor signaling compared to cells analyzed in poorly or adequately fed mice [26]. T-cells without selenoprotein expression (knockout of the selenoprotein specific tRNA) showed poorly raised serum levels of antigen-specific antibodies after immunization with different antigens [42]. Loss of selenoproteins under marginal selenium deficiency might therefore also be linked to a defective Tcell-mediated immune response.

In conclusion, the current data provide evidence for the suitability of the selenoproteins Sepw1, Gpx1, Selh, Selk and Sep15 as biomarkers for a marginal selenium deficiency in murine as well as in human leukocytes. In addition, inhibition of the inflammatory response under marginal selenium deficiency correlated with an up-regulation observed in selenium-supplemented human subjects. The correlations between selenium-dependent changes in gene expression in human and murine leukocytes make the murine data a reasonable basis to identify selenium-dependent biomarkers in humans.

Supplementary materials related to this article can be found online at doi:10.1016/j.jnutbio.2011.06.011. 


\section{Acknowledgments}

We thank Stefanie Deubel for excellent technical assistance and the team of the animal facilities especially Elke Thom and Swetlana König. Stan Gaj assisted in doing the data analysis.

\section{References}

[1] Kryukov GV, Castellano S, Novoselov SV, Lobanov AV, Zehtab O, Guigo R, et al. Characterization of mammalian selenoproteomes. Science 2003;300:1439-43.

[2] Bellinger FP, Raman AV, Reeves MA, Berry MJ. Regulation and function of selenoproteins in human disease. Biochem J 2009;422:11-22.

[3] Ip C. Lessons from basic research in selenium and cancer prevention. J Nutr 1998;128:1845-54.

[4] Ursini F, Heim S, Kiess M, Maiorino M, Roveri A, Wissing J, et al. Dual function of the selenoprotein PHGPx during sperm maturation. Science 1999;285:1393-6.

[5] Kupka R, Msamanga GI, Spiegelman D, Morris S, Mugusi F, Hunter DJ, et al. Selenium status is associated with accelerated HIV disease progression among HIV-1-infected pregnant women in Tanzania. J Nutr 2004;134:2556-60.

[6] Hurwitz BE, Klaus JR, Llabre MM, Gonzalez A, Lawrence PJ, Maher KJ, et al. Suppression of human immunodeficiency virus type 1 viral load with selenium supplementation: a randomized controlled trial. Arch Intern Med 2007;167:148-54.

[7] Hoffmann PR, Berry MJ. The influence of selenium on immune responses. Mol Nutr Food Res 2008;52:1273-80.

[8] Carlson BA, Yoo MH, Shrimali RK, Irons R, Gladyshev VN, Hatfield DL, et al. Role of selenium-containing proteins in T-cell and macrophage function. Proc Nutr Soc 2010;69:300-10.

[9] Beck MA. Antioxidants and viral infections: host immune response and viral pathogenicity. J Am Coll Nutr 2001;20:384S-8S discussion 96S-97S.

[10] Rayman MP. Food-chain selenium and human health: emphasis on intake. $\mathrm{Br} \mathrm{J}$ Nutr 2008;100:254-68.

[11] Forceville X, Vitoux D, Gauzit R, Combes A, Lahilaire P, Chappuis P. Selenium, systemic immune response syndrome, sepsis, and outcome in critically ill patients. Crit Care Med 1998;26:1536-44.

[12] Angstwurm MW, Schottdorf J, Schopohl J, Gaertner R. Selenium replacement in patients with severe systemic inflammatory response syndrome improves clinical outcome. Crit Care Med 1999;27:1807-13.

[13] Angstwurm MW, Engelmann L, Zimmermann T, Lehmann C, Spes CH, Abel P, et al. Selenium in Intensive Care (SIC): results of a prospective randomized, placebocontrolled, multiple-center study in patients with severe systemic inflammatory response syndrome, sepsis, and septic shock. Crit Care Med 2007;35:118-26.

[14] Vunta H, Belda BJ, Arner RJ, Channa Reddy C, Vanden Heuvel JP, Sandeep Prabhu K. Selenium attenuates pro-inflammatory gene expression in macrophages. Mol Nutr Food Res 2008;52:1316-23.

[15] Zamamiri-Davis F, Lu Y, Thompson JT, Prabhu KS, Reddy PV, Sordillo LM, et al. Nuclear factor-kappaB mediates over-expression of cyclooxygenase-2 during activation of RAW 264.7 macrophages in selenium deficiency. Free Radic Biol Med 2002;32:890-7.

[16] Zhang F, Yu W, Hargrove JL, Greenspan P, Dean RG, Taylor EW, et al. Inhibition of TNF-alpha induced ICAM-1, VCAM-1 and E-selectin expression by selenium. Atherosclerosis 2002;161:381-6.

[17] Banning A, Schnurr K, Böl GF, Kupper D, Müller-Schmehl K, Viita H, et al. Inhibition of basal and interleukin-1-induced VCAM-1 expression by phospholipid hydroperoxide glutathione peroxidase and 15-lipoxygenase in rabbit aortic smooth muscle cells. Free Radic Biol Med 2004;36:135-44.

[18] Banning A, Florian S, Deubel S, Thalmann S, Müller-Schmehl K, Jacobasch G, et al. GPx2 counteracts PGE2 production by dampening COX-2 and mPGES- 1 expression in human colon cancer cells. Antioxid Redox Signal 2008;10:1491-500.

[19] Vunta H, Davis F, Palempalli UD, Bhat D, Arner RJ, Thompson JT, et al. The antiinflammatory effects of selenium are mediated through 15-deoxy-Delta12,14prostaglandin J2 in macrophages. J Biol Chem 2007;282:17964-73.

[20] Rossi A, Kapahi P, Natoli G, Takahashi T, Chen Y, Karin M, et al. Anti-inflammatory cyclopentenone prostaglandins are direct inhibitors of IkappaB kinase. Nature 2000;403:103-8.

[21] Safir N, Wendel A, Saile R, Chabraoui L. The effect of selenium on immune functions of J774.1 cells. Clin Chem Lab Med 2003;41:1005-11.

[22] Mebius RE, Kraal G. Structure and function of the spleen. Nat Rev Immunol 2005:5:606-16

[23] Brendolan A, Rosado MM, Carsetti R, Selleri L, Dear TN. Development and function of the mammalian spleen. Bioessays 2007;29:166-77.

[24] Peng X, Cui H, Deng J, Zuo Z, Lai W. Histological lesion of spleen and inhibition of splenocyte proliferation in broilers fed on diets excess in selenium. Biol Trace Elem Res 2010;140:66-72.

[25] Vega L, Rodriguez-Sosa M, Garcia-Montalvo EA, Del Razo LM, Elizondo G. Nonoptimal levels of dietary selenomethionine alter splenocyte response and modify oxidative stress markers in female mice. Food Chem Toxicol 2007:45:1147-53.

[26] Hoffmann FW, Hashimoto AC, Shafer LA, Dow S, Berry MJ, Hoffmann PR. Dietary selenium modulates activation and differentiation of CD4+ T cells in mice through a mechanism involving cellular free thiols. J Nutr 2010;140:1155-61.

[27] Hoffmann PR, Jourdan-Le Saux C, Hoffmann FW, Chang PS, Bollt O, He Q, et al. A role for dietary selenium and selenoproteins in allergic airway inflammation. J Immunol 2007;179:3258-67.
[28] Kipp A, Banning A, van Schothorst EM, Meplan C, Schomburg L, Evelo C, et al. Four selenoproteins, protein biosynthesis, and Wnt signalling are particularly sensitive to limited selenium intake in mouse colon. Mol Nutr Food Res 2009;53:1561-72.

[29] Pagmantidis V, Méplan C, van Schothorst EM, Keijer J, Hesketh JE. Supplementation of healthy volunteers with nutritionally relevant amounts of selenium increases the expression of lymphocyte protein biosynthesis genes. Am J Clin Nutr 2008;87:181-9.

[30] National Research Council. Dietary selenium intake controls rat plasma selenoprotein $\mathrm{P}$ concentration. Nutrient requirements of laboratory animals. 4th ed. Washington, DC: National Academy Press; 1995. p. 80-102.

[31] van Schothorst EM, Pagmantidis V, de Boer VC, Hesketh J, Keijer J. Assessment of reducing RNA input for Agilent oligo microarrays. Anal Biochem 2007;363:315-7.

[32] Yang JJ, Yang MC. An improved procedure for gene selection from microarray experiments using false discovery rate criterion. BMC Bioinformatics 2006;7(e1-4):15.

[33] van Iersel MP, Kelder T, Pico AR, Hanspers K, Coort S, Conklin BR, et al. Presenting and exploring biological pathways with PathVisio. BMC Bioinformatics 2008;9:399.

[34] Pico AR, Kelder T, van Iersel MP, Hanspers K, Conklin BR, Evelo C. WikiPathways: pathway editing for the people. PLoS Biol 2008;6:e184.

[35] Vandesompele J, De Preter K, Pattyn F, Poppe B, Van Roy N, De Paepe A, et al. Accurate normalization of real-time quantitative RT-PCR data by geometric averaging of multiple internal control genes. Genome Biol 2002;3 RESEARCH0034.

[36] Bradford MM. A rapid and sensitive method for the quantitation of microgram quantities of protein utilizing the principle of protein-dye binding. Anal Biochem 1976;72:248-54.

[37] Florian S, Krehl S, Loewinger M, Kipp A, Banning A, Esworthy S, et al. Loss of GPx2 increases apoptosis, mitosis, and GPx1 expression in the intestine of mice. Free Radic Biol Med 2010;49:1694-702.

[38] Gromer S, Merkle H, Schirmer RH, Becker K. Human placenta thioredoxin reductase: preparation and inhibitor studies. Methods Enzymol 2002;347:382-94.

[39] Lemansky P, Gerecitano-Schmidek M, Das RC, Schmidt B, Hasilik A. Targeting myeloperoxidase to azurophilic granules in HL-60 cells. J Leukoc Biol 2003;74: $542-50$.

[40] de Mendez I, Young Jr KR, Bignon J, Lambre CR. Biochemical characteristics of alveolar macrophage-specific peroxidase activities in the rat. Arch Biochem Biophys 1991;289:319-23.

[41] Osserman EF, Lawlor DP. Serum and urinary lysozyme (muramidase) in monocytic and monomyelocytic leukemia. J Exp Med 1966;124:921-52.

[42] Shrimali RK, Irons RD, Carlson BA, Sano Y, Gladyshev VN, Park JM, et al. Selenoproteins mediate $\mathrm{T}$ cell immunity through an antioxidant mechanism. J Biol Chem 2008;283:20181-5.

[43] Sharif O, Bolshakov VN, Raines S, Newham P, Perkins ND. Transcriptional profiling of the LPS induced NF-kappaB response in macrophages. BMC Immunol 2007;8:1.

[44] Gao Y, Hannan NR, Wanyonyi S, Konstantopolous N, Pagnon J, Feng HC, et al. Activation of the selenoprotein SEPS1 gene expression by pro-inflammatory cytokines in HepG2 cells. Cytokine 2006;33:246-51.

[45] Liu Q, Lauridsen E, Clausen J. Different selenium-containing proteins in the extracellular and intracellular media of leucocytes cultivated in vitro. Biol Trace Elem Res 1998;61:237-52.

[46] Brigelius-Flohé R. Tissue-specific functions of individual glutathione peroxidases Free Radic Biol Med 1999;27:951-65.

[47] Schomburg L, Schweizer U. Hierarchical regulation of selenoprotein expression and sex-specific effects of selenium. Biochim Biophys Acta 2009;1790:1453-62.

[48] Sunde RA. Molecular biomarker panels for assessment of selenium status in rats. Exp Biol Med (Maywood) 2010;235:1046-52.

[49] Davies MJ, Hawkins CL, Pattison DI, Rees MD. Mammalian heme peroxidases: from molecular mechanisms to health implications. Antioxid Redox Signal 2008;10:1199-234.

[50] Hampton MB, Kettle AJ, Winterbourn CC. Inside the neutrophil phagosome: oxidants, myeloperoxidase, and bacterial killing. Blood 1998;92:3007-17.

[51] van der Veen BS, de Winther MP, Heeringa P. Myeloperoxidase: molecular mechanisms of action and their relevance to human health and disease. Antioxid Redox Signal 2009;11:2899-937.

[52] Schoonbroodt S, Legrand-Poels S, Best-Belpomme M, Piette J. Activation of the NFkappaB transcription factor in a T-lymphocytic cell line by hypochlorous acid. Biochem J 1997;321:777-85.

[53] Gloire G, Legrand-Poels S, Piette J. NF-kappaB activation by reactive oxygen species: fifteen years later. Biochem Pharmacol 2006;72:1493-505.

[54] Tolando R, Jovanovic A, Brigelius-Flohé R, Ursini F, Maiorino M. Reactive oxygen species and proinflammatory cytokine signaling in endothelial cells: effect of selenium supplementation. Free Radic Biol Med 2000;28:979-86.

[55] Kretz-Remy C, Mehlen P, Mirault ME, Arrigo AP. Inhibition of I kappa B-alpha phosphorylation and degradation and subsequent NF-kappa B activation by glutathione peroxidase overexpression. J Cell Biol 1996;133:1083-93.

[56] Brigelius-Flohé R, Maurer S, Lötzer K, Böl G, Kallionpää H, Lehtolainen P, et al. Overexpression of PHGPx inhibits hydroperoxide-induced oxidation, NFkappaB activation and apoptosis and affects oxLDL-mediated proliferation of rabbit aortic smooth muscle cells. Atherosclerosis 2000;152:307-16.

[57] Flohé L, Brigelius-Flohé R, Saliou C, Traber MG, Packer L. Redox regulation of NFkappa B activation. Free Radic Biol Med 1997;22:1115-26.

[58] Brigelius-Flohé R, Flohé L. Basic principles and emerging concepts in the redox control of transcription factors. Antioxid Redox Signal 2011;15:2335-81.

[59] Wang C, Wang H, Luo J, Hu Y, Wei L, Duan M, et al. Selenium deficiency impairs host innate immune response and induces susceptibility to Listeria monocytogenes infection. BMC Immunol 2009;10:55. 